\title{
Genomic architecture may influence recurrent chromosomal translocation frequency in the Igh locus
}

\section{Amy L. Kenter *, Robert Wuerffel, Satyendra Kumar and Fernando Grigera}

Department of Microbiology and Immunology, University of Illinois College of Medicine, Chicago, IL, USA

*Correspondence: star1@uic.edu

Edited by:

Ananda L. Roy, Tufts University School of Medicine, USA

Keywords: B cells, Igh locus, chromosomal translocations, AID, genomic structure

\section{INTRODUCTION}

B cell lymphomas represent $95 \%$ of all lymphomas diagnosed in the Western world and the majority of these arise from germinal center (GC) B cells (1). Recurrent chromosomal translocations involving Ig loci and proto-oncogenes are a hallmark of many types of B cell lymphoma (2). Three types of breakpoints can be identified in Ig loci. Translocation breakpoints adjacent to the $\mathrm{D}_{\mathrm{H}}$ or $\mathrm{J}_{\mathrm{H}}$ gene segments form secondary to $\mathrm{V}(\mathrm{D}) \mathrm{J}$ recombination, a process that occurs in early B cell development. Other translocations are located in rearranged $\mathrm{V}(\mathrm{D}) \mathrm{J}$ exons that have acquired mutations indicating that translocation is a byproduct of somatic hypermutation (SHM) which occurs in GC B cells. A third type of translocation is characterized by breakpoints in the Igh switch regions, a target for double strand DNA breaks (DSBs) during class switch recombination (CSR) that occurs in mature $B$ cells, both inside and outside the GC. Thus, in B lymphocytes, $\mathrm{V}(\mathrm{D}) \mathrm{J}$ joining, CSR, and SHM create obligate single- or double-strand DNA breaks as intermediates for chromosomal translocations $(3,4)$.

Activation-induced deaminase (AID) is the enzyme that initiates CSR and SHM (5) by inducing the formation of DSBs in switch $(\mathrm{S})$ regions and mutations in $\mathrm{V}$ gene exons (6-10). Studies indicate that non-Ig genes are mistargeted by AID (11, 12) and thereby acquire single and double strand DNA breaks at sites coincident with translocation breakpoints (1, 2). Mature B cells are particularly prone to chromosomal translocations that juxtapose Ig genes and proto-oncogenes, including c-myc [Burkitt's lymphoma (BL)], Bcl2 (follicular lymphoma), Bcl-6 (diffuse large cell lymphoma), and FGFR (multiple myeloma) and which are characteristic of human B cell malignancies (2). The mouse plasmacytoma (PCT) $\mathrm{T}(12 ; 15)($ Igh-myc) translocation, a direct counterpart of the human BL $\mathrm{t}(8 ; 14)(\mathrm{q} 24 ; \mathrm{q} 32)$ translocation, occurs as a dynamic process in mature $\mathrm{B}$ cells undergoing CSR and is dependent on the expression of AID $(13,14)$. Hence, a direct mechanistic link between AID and chromosomal translocations focused to Ig genes has been established.

One of the most puzzling aspects of recurrent chromosomal translocations is that DSBs on two different chromosomes must come into close proximity frequently enough to facilitate the crossover. How do the broken ends located at distal sites in cis or on trans chromosomes come together? Consideration of oncogenic selection, sources of translocation prone DSBs associated with antigen receptor rearrangements in $\mathrm{B}$ and $\mathrm{T}$ lymphocytes, and the role of DSB persistence in translocations have been recently reviewed $[(15,16)$ and references therein $]$. Here we consider the proposition that the spatial organization of mammalian genomes is intrinsically linked to genome stability and modulates the frequency of chromosomal translocations.

\section{A MODEL FOR RECURRENT CHROMOSOMAL TRANSLOCATIONS}

Two general models have been proposed to explain the non-random nature of higher order spatial genome organization and the correlation with chromosomal translocations (17). The "contact-first" model posits that translocations require pre-existing physical proximity, whereas, the "breakagefirst" model postulates that distant DSBs can be juxtaposed, perhaps through DNA repair machinery. These two theories, the dynamic "breakage-first" and the static "contact-first," differ fundamentally in their requirement for the presence of DSBs and the mobility of the broken ends.
In the contact-first model only limited local positional motion of DSBs is expected. In the breakage-first model, single DSBs are formed and must undergo large scale movement within nuclei to search for appropriate interaction partners. Although evidence for mobility has been found in yeast systems (18-20), the situation in mammalians cells appears different. In mammalian cells, damaged DNA is largely stationary over time (21-23). However, deprotected telomeres as well as joining of broken DNA ends during V(D)J recombination experience higher mobility $(24,25)$. Accordingly, the $\mathrm{V}_{\mathrm{H}}$ subdomain of the Igh locus has been described as spatially unstructured (26) although additional studies are required to confirm this conclusion. Nevertheless, the weight of evidence in mammalian systems favors the "contact-first" model in light of the limited spatial mobility of DSBs (27). Comparison of a genomic organization map with sites of chromosomal translocation revealed that the spatial proximity of two DSBs is a dominant factor in determining the translocation landscape genome-wide (28). Therefore, it is useful to examine the disposition of loci within chromatin architecture and how this influences the probability of two DSBs finding each other in nuclear space.

\section{THREE DIMENSIONAL ORGANIZATION OF THE MAMMALIAN GENOME}

Emerging evidence indicates that a fundamental property of the mammalian nucleus is the non-random organization of the genome in nuclear space (29). Cytogenetic studies reveal that the mammalian nucleus is occupied by non-randomly positioned genes and chromosomes (30). Together these studies have shown that gene activation or silencing is often associated with repositioning of that locus relative to nuclear compartments and 
other genomic loci. In this regard, it is relevant that in normal B cells, the breakage sites of several common translocations are more frequently found in close spatial proximity in the nucleus than would be expected based on random positioning (31). A similar relationship between translocation frequency and spatial proximity is observed in $\mathrm{BL}$ where the myc locus is on average closest to its most frequent translocation partner, Igh (32). The non-random aspect of genome spatial organization in a sub-compartmentalized nuclear space has emerged as a potential contributor to the genesis of chromosomal translocations (23).

The combination of new imaging tools and the comprehensive mapping of long range chromosomal interaction has revealed structural features and biological properties of the three dimensional (3D) genomic organization (33-38). Four features contributing to an ordered $3 \mathrm{D}$ organization of eukaryotic genomes have become evident. (1) Individual chromosomes occupy distinct chromosomal territories (CT) with only a limited degree of intermingling (39). (2) The eukaryotic genome is partitioned into functionally distinct euchromatin and heterochromatin (40). (3) Individual genomic loci and elements display preferences for nuclear positioning which correlates well with genomic functions including transcriptional activity and replication timing $(39,41)$. (4) Distant chromosomal elements associate to form chromatin loops thereby providing a mechanism for long range enhancer function $(36,38,42)$. These variables predict that unique and unanticipated spatial genomic relationships may determine unique combinations of chromosomal translocations that may differ in specific tissues and during differentiation.

\section{CHROMOSOMAL LOOPING INTERACTIONS FACILITATE CSR}

The best studied property of chromatin looping is the spatial proximity of genes and their regulatory elements to establish functional states. Of relevance here is the recognition that chromatin looping influences partner selection during $\mathrm{V}(\mathrm{D}) \mathrm{J}$ recombination (43-45), CSR $(46,47)$, and may drive specific chromosomal translocation events $(28,48,49)$. It is of importance to understand the spatial relationships within the Igh locus and how they relate to the preferential expression of Ig gene expression and protect against genome instability. We focus here on CSR because the most prevalent $\mathrm{B}$ cell lymphomas arise from GC B cells and are dependent on the expression of AID $(1,13,14)$.

Class switch recombination promotes diversification of $\mathrm{C}_{\mathrm{H}}$ effector function while retaining the original rearranged $\mathrm{V}(\mathrm{D}) \mathrm{J}$ exons. The mouse Igh locus spans $2.9 \mathrm{Mb}$ within which a centromeric $220 \mathrm{~kb}$ genomic region contains eight $\mathrm{C}_{\mathrm{H}}$ genes (encoding $\mu, \delta, \gamma 3, \gamma 1, \gamma 2 \mathrm{~b}, \gamma 2 \mathrm{a}, \varepsilon$, and $\alpha$ chains) each paired with repetitive $S$ DNA (with the exception of C $\delta$ ) (Figure 1A). CSR is focused on $\mathrm{S}$ regions and involves an intra-chromosomal deletional rearrangement (Figure 1B). Germline transcript (GLT) promoters, located upstream of I exon-S- $\mathrm{C}_{\mathrm{H}}$ regions, focus $\mathrm{CSR}$ to specific $S$ regions by differential transcription activation $(9,50)$. The I-S- $\mathrm{C}_{\mathrm{H}}$ region genes are embedded between the $\mathrm{E} \mu$ intronic and $3^{\prime} \mathrm{E} \alpha$ enhancers (51). Chromosome conformation capture (3C) studies reveal that in mature resting $\mathrm{B}$ cells the transcriptional enhancer elements, $\mathrm{E} \mu$ and $3^{\prime} \mathrm{E} \alpha$, engage in long range chromatin looping interactions $(46,47)$ (Figure 1C). B cell activation leads to induced recruitment of the GLT promoters to the $\mathrm{E} \mu: 3^{\prime} \mathrm{E} \alpha$ complex that in turn facilitates GLT expression and supports S/S synapsis (46).

The $3^{\prime} \mathrm{E} \alpha$ regulatory region plays a significant role in mediating the spatial structure of the Igh locus during CSR as well as promoting genome stability (52). Targeted deletion of hs $3 b, 4$ within $3^{\prime} \mathrm{E} \alpha$ abolishes GLT expression and GLT promoter: $3^{\prime} \mathrm{E} \alpha$ and $\mathrm{E} \mu: 3^{\prime} \mathrm{E} \alpha$ looping interactions (46, 53, 54). AID initiates a series of events ending in creation of $S$ region specific DNA DSBs at the donor $S \mu$ and a downstream acceptor $S$ region to create $S / S$ junctions and facilitate CSR (7).S regions targeted by AID for DSB formation are transcriptionally active. Chromatin looping across this region ensures proximity between two $S$ regions targeted for DSB creation and recombination (Figure 1C). Thus, CSR is dependent on $3 \mathrm{D}$ chromatin architecture mediated by long range intrachromosomal interactions between distantly located transcriptional elements that serves to tether broken chromosomal DNA together during the CSR reaction.
Chromosome conformation capture (3C, 4C, 5C, and Hi-C) based studies indicate that the most probable chromatin interactions are the most proximal ones and the probability of contact decreases with distance. Correspondingly, alignment of genomic organization maps with sites of chromosomal translocation generated in $\mathrm{Hi}-\mathrm{C}$ and $4 \mathrm{C}$ studies have shown that translocations are enriched in cis along single chromosomes containing the target DSB and in trans in a manner related to pre-existing spatial proximity $(28,55)$. The positional immobilization of DSBs in the Igh locus, for example, should render the probability of successful translocation as the product of the frequency of each DSB at the sites of crossover and the frequency with which these sites are synapsed in physical space (28). In B lymphocytes $c-m y c / I g h$ translocations occur in trans and may represent a failure of stringent spatial sequestration of AID induced DSBs to within the Igh locus $(56,57)$.

\section{DYNAMIC CHROMATIN INTERACTIONS AND THE GENESIS OF CHROMOSOMAL TRANSLOCATIONS}

Chromosomal translocation frequency as reported by genome-wide translocation sequencing is determined by the frequency of AID induced DSB at translocation targets, factors that contribute to synapsis of broken loci, and circumvention of DNA repair functions that facilitate intra-chromosomal DSB joining (5558). Are recurrent chromosomal translocations simply the result of a stochastic process related to the probability of contact between AID induced DSBs? Tagging single loci with Lac operon ( $\mathrm{LacO}$ ) arrays, as well as photobleaching and photoactivation experiments, have shown that interphase chromatin is locally mobile but rarely moves over long distances (59-61). However, lamina associated domains are large genomic regions that are in intermittent molecular contact with the nuclear lamina indicating a dynamic spatial architecture of chromosomes (62). Chromatin looping, clustering, and compartmentalization are dynamic and responsive to developmental and environmental cues. Functionally dynamic chromatin responses include formation of transcription and replication factories, and nuclear relocation of loci during development (63-66). The looping 


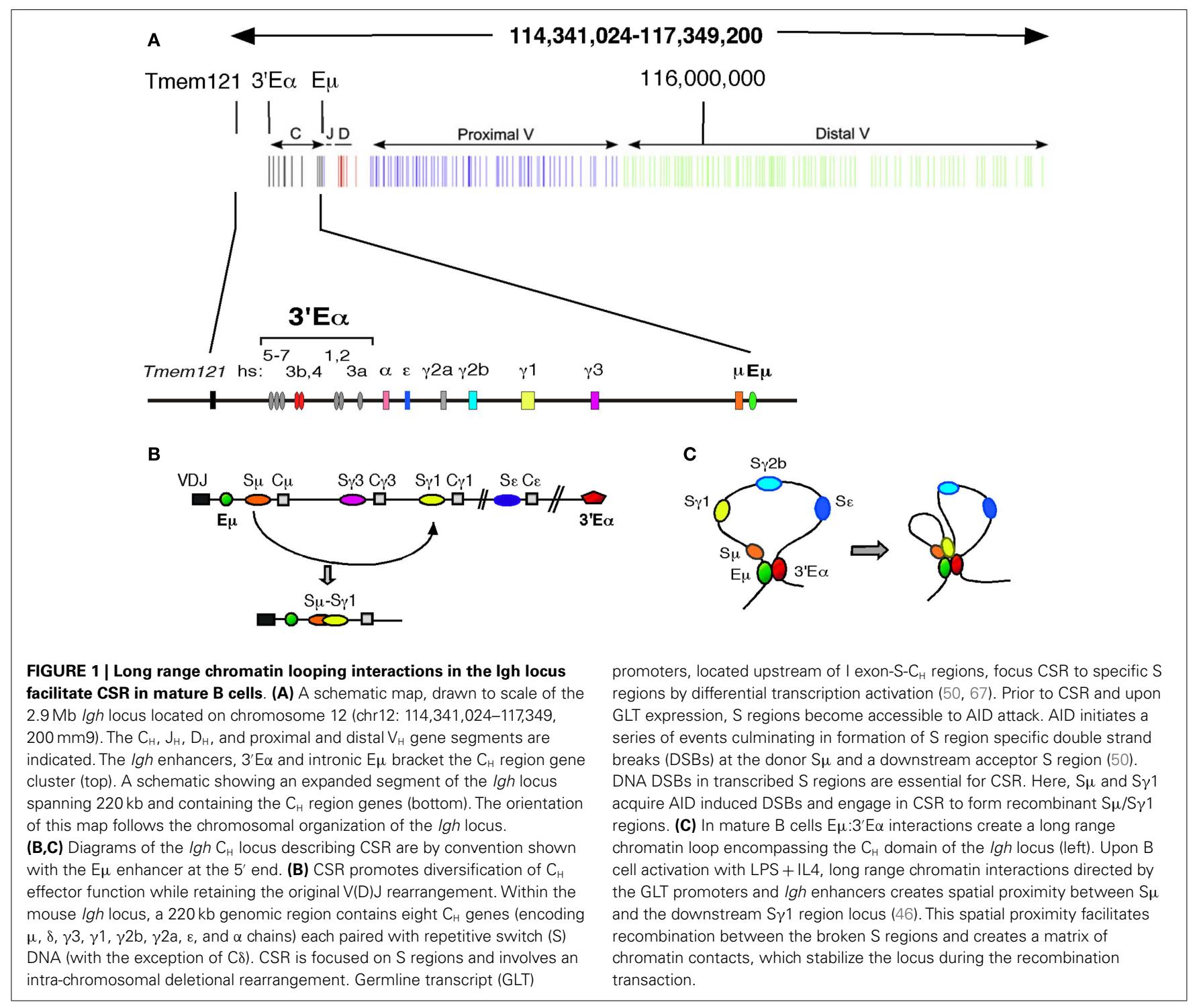

interactions spanning the Igh locus during CSR and in the presence of DSBs may also be dynamic and to some degree transient. In a dynamic chromosomal setting, DSBs present in an Igh locus that lacks $\mathrm{E} \mu: 3^{\prime} \mathrm{E} \alpha$ tethering, for example, would be at high risk of re-joining to sites outside the Igh locus along chromosome 12 and at lower frequency to sites on other chromosomes. The dynamism of chromosomal transactions are not yet fully described and represent the next forefront for investigation to appreciate constraints and variables of genome stability and instability.

\section{AUTHOR CONTRIBUTIONS}

Drs. Robert Wuerffel, Satyendra Kumar, Fernando Grigera, and Amy L. Kenter were all involved in developing the ideas regarding long range chromatin interactions and dynamics that are the subject here and all have critiqued and agree to the contents of this piece. Amy L. Kenter wrote the article.

\section{ACKNOWLEDGMENTS}

This work was supported by the National Institutes of Health RO1AI052400 and R21AI106328 to Amy L. Kenter.

\section{REFERENCES}

1. Kuppers R. Mechanisms of B-cell lymphoma pathogenesis. Nat Rev Cancer (2005) 5:251-62. doi: $10.1038 / \mathrm{nrc1589}$

2. Kuppers R, Dalla-Favera R. Mechanisms of chromosomal translocations in B cell lymphomas. Oncogene (2001) 20:5580-94. doi:10.1038/sj.onc. 1204640
3. Nussenzweig A, Nussenzweig MC. Origin of chromosomal translocations in lymphoid cancer. Cell (2010) 141:27-38. doi:10.1016/j.cell.2010.03. 016

4. Tsai AG, Lu H, Raghavan SC, Muschen M, Hsieh CL, Lieber MR. Human chromosomal translocations at $\mathrm{CpG}$ sites and a theoretical basis for their lineage and stage specificity. Cell (2008) 135:1130-42. doi:10.1016/j.cell.2008.10.035

5. Muramatsu M, Kinoshita K, Fagarasan S, Yamada S, Shinkai Y, Honjo T. Class switch recombination and hypermutation require activation-induced cytidine deaminase (AID), a potential RNA editing enzyme. Cell (2000) 102:553-63. doi:10.1016/ S0092-8674(00)00078-7

6. Chahwan R, Edelmann W, Scharff MD, Roa S. AIDing antibody diversity by error-prone mismatch repair. Semin Immunol (2012) 24:293-300. doi:10. 1016/j.smim.2012.05.005

7. Kenter AL. AID targeting is dependent on RNA polymerase II pausing. Semin Immunol (2012) 24:281-6. doi:10.1016/j.smim.2012.06.001 
8. Pavri R, Gazumyan A, Jankovic M, Di Virgilio M, Klein I, Ansarah-Sobrinho C, et al. Activationinduced cytidine deaminase targets DNA at sites of RNA polymerase II stalling by interaction with Spt5. Cell (2010) 143:122-33. doi:10.1016/j.cell. 2010.09.017

9. Stavnezer J, Guikema JE, Schrader CE. Mechanism and regulation of class switch recombination. Annu Rev Immunol (2008) 26:261-92. doi: 10.1146/annurev.immunol.26.021607.090248

10. Peled JU, Kuang FL, Iglesias-Ussel MD, Roa S, Kalis SL, Goodman MF, et al. The biochemistry of somatic hypermutation. Annu Rev Immunol (2008) 26:481-511. doi:10.1146/ annurev.immunol.26.021607.090236

11. Shen HM, Peters A, Baron B, Zhu X, Storb U. Mutation of BCL- 6 gene in normal B cells by the process of somatic hypermutation of Ig genes. Science (1998) 280:1750-2. doi:10.1126/science.280. 5370.1750

12. Kotani AI, Okazaki M, Muramatsu M, Kinoshita K, Begum NA, Nakajima T, et al. A target selection of somatic hypermutations is regulated similarly between $\mathrm{T}$ and $\mathrm{B}$ cells upon activationinduced cytidine deaminase expression. Proc Natl Acad Sci U S A (2005) 102:4506-11. doi:10.1073/ pnas.0500830102

13. Ramiro AR, Jankovic M, Callen E, Difilippantonio S, Chen HT, McBride KM, et al. Role of genomic instability and p53 in AID-induced cmyc-Igh translocations. Nature (2006) 440:105-9. doi:10.1038/nature04495

14. Ramiro AR, Jankovic M, Eisenreich T, Difilippantonio S, Chen-Kiang S, Muramatsu M, et al. AID is required for $\mathrm{c}-\mathrm{myc} / \mathrm{IgH}$ chromosome translocations in vivo. Cell (2004) 118:431-8. doi:10.1016/ j.cell.2004.08.006

15. Alt FW, Zhang Y, Meng FL, Guo C, Schwer B. Mechanisms of programmed DNA lesions and genomic instability in the immune system. Cell (2013) 152:417-29. doi:10.1016/j.cell.2013.01.007

16. Gostissa M, Alt FW, Chiarle R. Mechanisms that promote and suppress chromosomal translocations in lymphocytes. Annu Rev Immunol (2011) 29:319-50. doi:10.1146/annurevimmunol-031210-101329

17. Misteli T, Soutoglou E. The emerging role of nuclear architecture in DNA repair and genome maintenance. Nat Rev Mol Cell Biol (2009) 10:243-54. doi:10.1038/nrm2651

18. Lisby M, Antunez de Mayolo A, Mortensen UH, Rothstein R. Cell cycle-regulated centers of DNA double-strand break repair. Cell Cycle (2003) 2:479-83. doi:10.4161/cc.2.5.483

19. Lisby M, Mortensen UH, Rothstein R. Colocalization of multiple DNA double-strand breaks at a single Rad52 repair centre. Nat Cell Biol (2003) 5:572-7. doi: $10.1038 /$ ncb997

20. Lisby M, Rothstein R. DNA damage checkpoint and repair centers. Curr Opin Cell Biol (2004) 16:328-34. doi:10.1016/j.ceb.2004.03.011

21. Nelms BE, Maser RS, MacKay JF, Lagally MG, Petrini JH. In situ visualization of DNA doublestrand break repair in human fibroblasts. Science (1998) 280:590-2. doi:10.1126/science.280.5363. 590

22. Kruhlak MJ, Celeste A, Nussenzweig A. Spatiotemporal dynamics of chromatin containing DNA breaks. Cell Cycle (2006) 5:1910-2. doi:10.4161/cc. 5.17.3169

23. Meaburn KJ, Misteli T, Soutoglou E. Spatial genome organization in the formation of chromosomal translocations. Semin Cancer Biol (2007) 17:80-90. doi:10.1016/j.semcancer.2006.10.008

24. Dimitrova N, Chen YC, Spector DL, de Lange T. 53BP1 promotes non-homologous end joining of telomeres by increasing chromatin mobility. Nature (2008) 456:524-8. doi:10.1038/ nature 07433

25. Difilippantonio S, Gapud E, Wong N, Huang CY, Mahowald G, Chen HT, et al. 53BP1 facilitates long-range DNA end-joining during V(D)J recombination. Nature (2008) 456:529-33. doi:10.1038/ nature 07476

26. Medvedovic J, Ebert A, Tagoh H, Tamir IM, Schwickert TA, Novatchkova $\mathrm{M}$, et al. Flexible long-range loops in the $\mathrm{VH}$ gene region of the Igh locus facilitate the generation of a diverse antibody repertoire. Immunity (2013) 39:229-44. doi:10.1016/j.immuni.2013.08.011

27. Soutoglou E, Dorn JF, Sengupta K, Jasin M, Nussenzweig A, Ried T, et al. Positional stability of single double-strand breaks in mammalian cells. Nat Cell Biol (2007) 9:675-82. doi:10.1038/ ncb1591

28. Zhang Y, McCord RP, Ho YJ, Lajoie BR, Hildebrand DG, Simon AC, et al. Spatial organization of the mouse genome and its role in recurrent chromosomal translocations. Cell (2012) 148:908-21. doi:10.1016/j.cell.2012.02.002

29. Lanctot C, Cheutin T, Cremer M, Cavalli G, Cremer T. Dynamic genome architecture in the nuclear space: regulation of gene expression in three dimensions. Nat Rev Genet (2007) 8:104-15. doi:10.1038/nrg2041

30. Meaburn KJ, Misteli T. Cell biology: chromosome territories. Nature (2007) 445:379-781. doi: $10.1038 / 445379$ a

31. Neves H, Ramos C, da Silva MG, Parreira A, Parreira L. The nuclear topography of ABL, BCR, PML, and RARalpha genes: evidence for gene proximity in specific phases of the cell cycle and stages of hematopoietic differentiation. Blood (1999) 93:1197-207.

32. Roix JJ, McQueen PG, Munson PJ, Parada LA, Misteli T. Spatial proximity of translocation-prone gene loci in human lymphomas. Nat Genet (2003) 34:287-91. doi:10.1038/ng1177

33. Baker M. Genomics: genomes in three dimensions. Nature (2011) 470:289-94. doi:10.1038/470289a

34. Osborne CS, Ewels PA, Young AN. Meet the neighbours: tools to dissect nuclear structure and function. Brief Funct Genomics (2011) 10:11-7. doi:10. 1093/bfgp/elq034

35. van Steensel B, Dekker J. Genomics tools for unraveling chromosome architecture. Nat Biotechnol (2010) 28:1089-95. doi:10.1038/nbt.1680

36. Naumova $\mathrm{N}$, Dekker J. Integrating onedimensional and three-dimensional maps of genomes. J Cell Sci (2010) 123:1979-88. doi:10.1242/jcs.051631

37. Cavalli G, Misteli T. Functional implications of genome topology. Nat Struct Mol Biol (2013) 20:290-9. doi:10.1038/nsmb.2474

38. Dixon JR, Selvaraj S, Yue F, Kim A, Li Y, Shen $\mathrm{Y}$, et al. Topological domains in mammalian genomes identified by analysis of chromatin interactions. Nature (2012) 485:376-80. doi:10.1038/ nature 11082

39. Cremer T, Cremer M. Chromosome territories. Cold Spring Harb Perspect Biol (2010) 2:a003889. doi:10.1101/cshperspect.a003889

40. Felsenfeld G, Groudine M. Controlling the double helix. Nature (2003) 421:448-53. doi:10.1038/ nature01411

41. Takizawa T, Meaburn KJ, Misteli T. The meaning of gene positioning. Cell (2008) 135:9-13. doi:10.1016/j.cell.2008.09.026

42. Lieberman-Aiden E, van Berkum NL, Williams L, Imakaev M, Ragoczy T, Telling A, et al. Comprehensive mapping of long-range interactions reveals folding principles of the human genome. Science (2009) 326:289-93. doi:10.1126/science. 1181369

43. Guo C, Gerasimova T, Hao H, Ivanova I, Chakraborty T, Selimyan R, et al. Two forms of loops generate the chromatin conformation of the immunoglobulin heavy-chain gene locus. Cell (2011) 147:332-43. doi:10.1016/j.cell.2011.08.049

44. Guo C, Yoon HS, Franklin A, Jain S, Ebert A, Cheng HL, et al. CTCF-binding elements mediate control of V(D)J recombination. Nature (2011) 477:424-30. doi:10.1038/nature10495

45. Jhunjhunwala S, van Zelm MC, Peak MM, Murre C. Chromatin architecture and the generation of antigen receptor diversity. Cell (2009) 138:435-48. doi:10.1016/j.cell.2009.07.016

46. Wuerffel R, Wang L, Grigera F, Manis J, Selsing E, Perlot $\mathrm{T}$, et al. S-S synapsis during class switch recombination is promoted by distantly located transcriptional elements and activationinduced deaminase. Immunity (2007) 27:711-22. doi:10.1016/j.immuni.2007.09.007

47. Sellars M, Reina-San-Martin B, Kastner P, Chan S. Ikaros controls isotype selection during immunoglobulin class switch recombination. J Exp Med (2009) 206:1073-87. doi:10.1084/jem. 20082311

48. Lin C, Yang L, Tanasa B, Hutt K, Ju BG, Ohgi K, et al. Nuclear receptor-induced chromosomal proximity and DNA breaks underlie specific translocations in cancer. Cell (2009) 139:1069-83. doi:10.1016/j. cell.2009.11.030

49. Mani RS, Tomlins SA, Callahan K, Ghosh A, Nyati MK, Varambally S, et al. Induced chromosomal proximity and gene fusions in prostate cancer. Science (2009) 326:1230. doi:10.1126/science. 1178124

50. Chaudhuri J, Basu U, Zarrin A, Yan C, Franco S, Perlot $\mathrm{T}$, et al. Evolution of the immunoglobulin heavy chain class switch recombination mechanism. Adv Immunol (2007) 94:157-214. doi:10. 1016/S0065-2776(06)94006-1

51. Perlot T, Alt FW. Cis-regulatory elements and epigenetic changes control genomic rearrangements of the IgH locus. Adv Immunol (2008) 99:1-32. doi:10.1016/S0065-2776(08)00601-9

52. Gostissa M, Yan CT, Bianco JM, Cogne M, Pinaud E, Alt FW. Long-range oncogenic activation of Igh-c-myc translocations by the Igh $3^{\prime}$ regulatory region. Nature (2009) 462:803-7. doi:10. 1038/nature08633

53. Pinaud E, Khamlichi AA, Le Morvan C, Drouet M, Nalesso V, Le Bert $M$, et al. Localization 
of the $3^{\prime}$ IgH locus elements that effect longdistance regulation of class switch recombination. Immunity (2001) 15:187-99. doi:10.1016/S10747613(01)00181-9

54. Pinaud E, Marquet M, Fiancette R, Peron S, Vincent-Fabert C, Denizot $\mathrm{Y}$, et al. The IgH locus $3^{\prime}$ regulatory region: pulling the strings from behind. Adv Immunol (2011) 110:27-70. doi:10. 1016/B978-0-12-387663-8.00002-8

55. Rocha PP, Micsinai M, Kim JR, Hewitt SL, Souza PP, Trimarchi T, et al. Close proximity to Igh is a contributing factor to AID-mediated translocations. Mol Cell (2012) 47:873-85. doi:10.1016/j.molcel. 2012.06.036

56. Chiarle R, Zhang Y, Frock RL, Lewis SM, Molinie B, Ho YJ, et al. Genome-wide translocation sequencing reveals mechanisms of chromosome breaks and rearrangements in B cells. Cell (2011) 147:107-19. doi:10.1016/j.cell.2011.07. 049

57. Klein IA, Resch W, Jankovic M, Oliveira T, Yamane A, Nakahashi H, et al. Translocationcapture sequencing reveals the extent and nature of chromosomal rearrangements in B lymphocytes. Cell (2011) 147:95-106. doi:10.1016/j.cell.2011.07. 048

58. Hakim O, Resch W, Yamane A, Klein I, KiefferKwon KR, Jankovic M, et al. DNA damage defines sites of recurrent chromosomal translocations in B lymphocytes. Nature (2012) 484:69-74. doi:10. 1038/nature10909
59. Walter J, Schermelleh L, Cremer M, Tashiro S, Cremer T. Chromosome order in HeLa cells changes during mitosis and early G1, but is stably maintained during subsequent interphase stages. J Cell Biol (2003) 160:685-97. doi:10.1083/jcb. 200211103

60. Strickfaden H, Zunhammer A, van Koningsbruggen S, Kohler D, Cremer T. 4D chromatin dynamics in cycling cells: Theodor Boveri's hypotheses revisited. Nucleus (2010) 1:284-97. doi:10.4161/nucl.1.3.11969

61. Thomson I, Gilchrist S, Bickmore WA, Chubb JR. The radial positioning of chromatin is not inherited through mitosis but is established de novo in early G1. Curr Biol (2004) 14:166-72. doi:10.1016/j.cub.2003.12.024

62. Kind J, Pagie L, Ortabozkoyun H, Boyle S, de Vries SS, Janssen H, et al. Single-cell dynamics of genome-nuclear lamina interactions. Cell (2013) 153:178-92. doi:10.1016/j.cell.2013.02.028

63. Rajapakse I, Perlman MD, Scalzo D, Kooperberg C, Groudine M, Kosak ST. The emergence of lineagespecific chromosomal topologies from coordinate gene regulation. Proc Natl Acad Sci U S A (2009) 106:6679-84. doi:10.1073/pnas.0900986106

64. Peric-Hupkes D, Meuleman W, Pagie L, Bruggeman SW, Solovei I, Brugman W, et al. Molecular maps of the reorganization of genome-nuclear lamina interactions during differentiation. Mol Cell (2010) 38:603-13. doi:10.1016/j.molcel.2010. 03.016
65. Edelman LB, Fraser P. Transcription factories: genetic programming in three dimensions. Curr Opin Genet Dev (2012) 22:110-4. doi:10.1016/j. gde.2012.01.010

66. Kosak ST, Skok JA, Medina KL, Riblet R, Le Beau MM, Fisher AG, et al. Subnuclear compartmentalization of immunoglobulin loci during lymphocyte development. Science (2002) 296:158-62. doi:10.1126/science. 1068768

67. Stavnezer J. Molecular processes that regulate class switching. Curr Top Microbiol Immunol (2000) 245:127-68.

Received: 03 December 2013; accepted: 18 December 2013; published online: 30 December 2013.

Citation: Kenter AL, Wuerffel R, Kumar S and Grigera $F$ (2013) Genomic architecture may influence recurrent chromosomal translocation frequency in the Igh locus. Front. Immunol. 4:500. doi: 10.3389/fimmu.2013.00500 This article was submitted to B Cell Biology, a section of the journal Frontiers in Immunology.

Copyright $\odot 2013$ Kenter, Wuerffel, Kumar and Grigera. This is an open-access article distributed under the terms of the Creative Commons Attribution License (CC BY). The use, distribution or reproduction in other forums is permitted, provided the original author(s) or licensor are credited and that the original publication in this journal is cited, in accordance with accepted academic practice. No use, distribution or reproduction is permitted which does not comply with these terms. 